work of the different centres to be visited by the association, and by means of correspondence, circulars, \&c., to keep them in touch with each other and with the executive in England.

The centres, which are seven in number, are as follows :-Cape Town, Durban, Pietermaritzburg, Johannesburg, Bloemfontein, Kimberley, and Bulawayo. Influential local committees have been formed at all these places, the municipal authorities of which have taken a prominent part both in making general arrangements and in affording financial support. Subcommittees for finance, publications, excursions, and hospitality have been formed at the two chief centres (Cape Town and Johannesburg), and are now engaged in the respective parts of the work allotted to them. At the other centres where a stay of only a day or two is contemplated, special committees have also been formed. Details are as yet uncertain, but the following may be mentioned, though some of them are subject to slight revision.

The officers of the association and invited guests to the number of 200 , along with ordinary members, will arrive by the Saxon at Cape Town on August ${ }^{15}$, though a number have already booked their passage by steamers arriving at an earlier date. The presidential address will be delivered on the evening of the same day in the large new Town Hall, which has been placed at the disposal of the British Association by the municipal authorities of Cape Town, not only for this purpose, but also for the accommodation of the various sections should it prove suitable.

The sections will meet for the purpose of reading papers and for discussion on Wednesday, Thursday, and Friday, August 16,17 , and 18 . The afternoons of these days will be partly devoted to excursions to places of interest, such as Table Mountain, Hout Bay, Simons Town, and Royal Observatory. The whole of Saturday, August 19, will be devoted to excursions.

The evenings will probably be devoted to a reception by the Mayor, and two lectures, one by Prof. Poulton on Burchell's work in South Africa, and another by Mr. C. V. Boys on physics.

On Saturday night, August I9, visitors will leave by a special steamer for Durban. In Natal an influential general committee has been formed by the Government, with local committees at Durban, Pietermaritzburg, and Ladysmith. On the evening of August 20 a lecture will be delivered at Durban and another on August 24 at Pietermaritzburg. As the reading of papers, discussions, receptions, \&c., in Cape Colony will fully occupy all the time of the visitors, it is intended to afford as much facility as possible for independent action on the part of visitors in Natal, and special arrangements will be made by the Natal committee for visiting the battlefields and other places of interest.

The sectional work will be again resumed on arrival of the party at Johannesburg on Monday, August 28. There, as at Cape Town, a large and influential local committee has been formed, with subcommittees for finance, hospitality, publication, and excursions. The first-named subcommittee has already met with a ready response, both from the municipal authorities and from private sources, and the other committees are in capable hands. While the natural facilities for excursions to be found near the Cape peninsula are not to be met with here, the interest of the mining operations and gold extracting processes will be an adequate compensation, and a Friday's visit to Pretoria will be of special interest.

The proceedings will be begun at Johannesburg on Monday evening, August 28, and the presidential address there will be delivered on the Wednesday evening. In addition to sectional papers and discussions, there will be two lectures delivered at Johannesburg, one on distribution of power by Prof. Ayrton, another on steel as an igneous rock by Prof. Arnold, and one at Pretoria by Prof. Porter on mining.

Bloemfontein will be visited on Saturday, September 2. There also an influential local committee has been formed, and preparations are being made for the reception of visitors. A lecture will be delivered there on the Saturday night by Mr. A. R. Hinks on an astronomical subject.

At Kimberley, which will be reached on Tuesday, September 5, a large local committee has been formed, with subcommittees for special objects. Two lectures will probably be delivered here, one on a zoological subject by Mr. A. E. Shipley, and one on diamonds by Sir William Crookes. The De Beers Company has naturally taken a prominent part in the preparations, and will probably make this visit one of the most interesting.

Through the kindness of the Chartered Company a limited number of members of the British Association will be enabled to proceed from there to the Zambezi, where the Victoria Falls will be visited, and facilities will be afforded for the visit of a select party of specialists to the ancient ruins of Zimbabwe. A special committee at Bulawayo has been formed to make preparations there for the visit.

Special attention will be directed to certain interesting problems connected with the geological formation at the Victoria Falls, and Mr. G. W. Lamplugh, who will go out in advance to study this subject, will probably be able to give the results of his observations in an afternoon address to Section C.

Though this meeting of the association will be characterised by the number and variety of the places visited, a special feature will be the study of local scientific problems and discussions of a general nature such as fossil reptiles, Antarctica, \&c. With this in view the South African Association for the Advancement of Science, with the support of the various Governments, is preparing a handbook, which will be a general review of the various branches of scientific activity in South Africa, the articles being contributed by actual workers in these subjects in the country. The book is now in an advanced stage of preparation, and a copy will be presented to each member of the association before leaving England.

\section{SIR BERNHARD SAMUELSON, P.C., BART., F.R.S.}

GIR BERNHARD SAMUELSON, F.R.S., who $S$ died on May to in his eighty-fifth year, will be remembered as one of the pioneers of the Cleveland iron trade, and a strenuous advocate of technical education. He exerted a great and formative influence upon an industry which owes its progress largely to the application of scientific methods, and the extension of facilities for technical education is largely due to his efforts.

Sir Bernhard Samuelson was born on November 22 , 1820 , and began in 1853 the business which speedily made the Cleveland district the greatest iron-producing centre in the world. Blast furnaces were erected near Middlesbrough, and in $1872-1880$ collieries and ironstone mines were added. Not content with making pig-iron, the manufacture of finished iron was undertaken on an extensive scale, and no less than $25,000 l$. were spent in preliminary experiments in steel-making. The Britannia Ironworks at Middlesbrough, covering an area of twenty acres, have grown out of this enterprise.

$\mathrm{He}$ was the author of several reports on technical subjects to the House of Commons, including one on technical education of artisans at home and abroad.

NO. I 855 , voL. 72$]$ 
This report was undertaken by Sir Bernhard Samuelson in 1867 at the request of the vice-president of the Committee of Council, and for the purpose of obtaining particulars he visited the principal manufacturing centres of Great Britain and the Continent. The report was published as a Parliamentary paper, and the Times records that it was for years referred to in all debates on technical education. He followed up this report by a Parliamentary inquiry into the education of the workmen of our manufactories in 1868 , and was chairman of the committee, the report of which was adopted by the House of Commons. He was a member of the Duke of Devonshire's Royal Commission on Scientific Instruction, which issued a valuable report, and also of the Royal Commission on Elementary Education, presided over by Viscount Cross.

Sir Bernhard Samuelson was appointed chairman of the Royal Commission on Technical Instruction, the labours of which extended over the years 1882, $188_{3}$, and $188_{4}$, and embraced an examination into the systems in use in all parts of the United Kingdom and a great portion of the Continent of Europe. The exhaustive report of the Commission has become the standard authority upon the questions with which it deals. In I 888 he was appointed a member of the Parliamentary Committee for inquiring into the working of the Education Acts.

For his scientific work, Sir Bernhard Samuelson was elected a Fellow of the Royal Society in I88I, and for his many public services he was created a baronet in 1884, and was afterwards made a Privy Councillor. $\mathrm{He}$ was a member of the Institutions of Civil and Mechanical Engineers, and was the recipient, in 1871 , of the Telford gold medal for a paper on improvements in iron manufactures. He was a member of the council of the Iron and Steel Institute, of which he occupied the presidential chair for two years. At the annual meeting of the institute held last week, the following resolution was unanimously adopted:"The council have received with the deepest regret the intimation of the death of their esteemed colleague the Right Hon. Sir Bernhard Samuelson, Bart., past-president, P.C., and one of the founders of the institute, and they desire to convey to Lady Samuelson and his family an expression of sincere sympathy in their bereavement. The council feel that it would be difficult to over-rate the services that Sir Bernhard rendered to the Iron and Steel Institute in the promotion of the objects for which it was formed, and they will ever remember with gratitude his constant readiness to devote his time and energies to the advancement of those objects."

\section{DR. OTTO VON STRUVE.}

THE announcement of the death of Dr. Otto von Struve does more than awaken a profound regret. His name recalls a period of past history, and summons up before us the memory of times when astronomy occupied a different position from that it assumes today, when it had fewer objects of interest wherewith to attract, and offered fewer problems for solution. Fifty-five years have gone since Otto von Struve received at the hands of the late Astronomer Royal the medal of the Royal Astronomical Society for his paper on precession and solar motion, and sixty-five since the paper was published. Seeing that Struve was born in I819, he early came into prominence as an astronomer, and the value attached to the results and the confidence inspired by the paper are not a little remarkable, for there were some very obvious objections which might have been taken to the conclusions stated, or at least NO. I 855 , vOL. 72$]$ it appears so when viewed from a later standpoint. Accompanying the paper was also a discussion of the amount and direction of the solar motion. Only four years had elapsed since Argelander had published his paper assigning with some precision the place of the solar apex, and thus perhaps settling a doubt which had long divided astronomical thought. Prevost and Klugel had taken one side of the question, and Burckhardt and Lindenau led the party who were unwilling to accept the evidence. Men's minds were certainly divided as to the possibility of detecting the sun's motion, and Struve's paper came at a fortunate moment and strengthened the evidence produced by Argelander, for, based on very different material, Struve's position scarcely differed two degrees from that assigned by the Abo astronomer. Also, Struve was fairly fortunate in fixing the annual amount of the solar motion at about twice that of the radius of the earth's orbit. Later investigations have shown that a greater velocity is probable, but he was certainly correct in asserting that the linear motion of the sun appeared to be less than that of stars in gerieral.

But it was in the domain of double stars that Otto von Struve won his reputation, and it was in this direction that he exhibited untiring industry. His father at Dorpat, and later at Pulkova, had not only devoted himself with great energy to this branch of astronomy, but had introduced a degree of accuracy into the observations that up to his time had been wanting. Otto von Struve, anxious to uphold the family reputation, was as diligent to detect these objects and as accurate in his observations as. was his father before him, though he laboured under some peculiar difficulty as an observer, and was obliged to remove a systematic error which affected his observations by introducing a correction depending upon the distance of the component stars--a correction investigated with great care by means of artificial double stars.

From 186r, on the failing health of his father, Otto von Struve became the director of the Imperial Observatory at Pulkova, and in every department maintained the reputation for accuracy the observatory had won. In meridian places of stars, in cometary observations, in geodesy, in spectroscopy, the activity and efficiency of the institution have been everywhere acknowledyed. In expeditions, whether for the transit of Venus or for eclipse work, the observatory has displayed its zeal and its desire to cooperate with similar work carried on elsewhere. Instruments have been renewed as needed, and the erection of the 30 -inch refractor testifies to the determination to keep the observatory on a level with those best equipped. Under the care of the late director, splendid laboratories have arisen devoted to spectroscopic inquiries, and it is not too much to say that his direction of a world-famous observatory has been of a most enlightened and beneficent character. The recipient of many honours, he retired from the observatory in 1893 to enjoy the repose to which he was so well entitled amid the society of his many friends.

\section{NOTES.}

The Croonian lecture of the Royal Society will be delivered by Mr. W. B. Hardy, F.R.S., on Thursday next, May 25, on "The Globulins."

By the creation of the Committee of Defence, the functions and views of which were described by $\mathrm{Mr}$. Balfour in the House of Commons on Thursday last, an expert advisory body has been introduced into the councils of the Government. In the discussion which followed the speech of the Prime Minister, Mr. Haldane remarked that millions of money uselessly expended would have been saved to the 